\title{
LANDASAN DAKWAH MULTIKULTURAL: STUDI KASUS FATWA MUI TENTANG PENGHARAMAN PLURALISME AGAMA
}

\author{
Aris Kristianto \\ STID Al-Hadid, Surabaya \\ ariskristianto6@gmail.com
}

\author{
Dedy Pradesa \\ STID Al-Hadid, Surabaya \\ depra19312@gmail.com
}

\begin{abstract}
Abstrak: Studi ini berangkat dari gagasan dakwah multikultural yang relevan dengan konteks Indonesia. Sebagai sebuah pendekatan dakwah berbasis multikultural perlu memiliki landasan yang tepat dalam pelaksanaannya, karena konsep multikultural bersinggungan dengan konsep pluralisme teologis yang ternyata maknanya tidak tunggal. Sisi lain MUI sebagai Lembaga yang mengeluarkan fatwa Nomor 7 Tahun 2005 tentang keharaman pluralisme. Di sinilah perlunya pengkajian fatwa MUI tentang pengharaman pluralisme teologis sebagai landasan dakwah multikultural. Studi ini berfokus pada menelaah fatwa MUI tentang pengharaman pluralisme agama dan keabsahan makna khusus pluralisme agama, serta implikasi fatwa tersebut bagi pelaksanaan dakwah multikultural. Metodologi studi secara kualitatif deskriptif dengan pendekatan kepustakaan. Analisis berpijak pada konsep pluralisme, karakteristik dakwah multikultural, serta kelembagaan MUI dan fatwanya. Hasil studi menunjukkan bahwa pemaknaan pluralisme yang digagas MUI absah sebab berangkat dari pengertian awal pemahaman masyarakat, sehingga fatwa tersebut dapat diterima kebenarannya. Implikasi fatwa tersebut terletak pada tiga hal, yaitu perlunya pengembangan materi antipluralisme dan promultikultural, pengembangan strategi dakwah berbasis kultural dan mengedepankan kerukunan, penyikapan perbedaan dengan dialog dan toleransi aktif untuk hidup Bersama.
\end{abstract}

Kata kunci: Dakwah multikultural, Fatwa MUI, Pluralisme agama

\begin{abstract}
This study is taken from a concept of multicultural da'wah relevant to the Indonesian context. As an approach, multicultural da'wah needs to own the right basis in its implementation, since the multicultural concept is related to the concept of religious pluralism whose meaning is, in reality, not single. Meanwhile, MUI, as an institution issuing Islamic decree (fatwa) in Indonesia, has issued a fatwa on the prohibition for religious pluralism, its meaning legality, and its fatwa implication for the implementation of multicultural da'wah. This study applies qualitative descriptive method with library-research approach. Its analysis is based on the pluralism concept, multicultural da'wah characteristics, the institution of MUI, and its fatwa. The result shows that the definition of pluralism which was initiated by MUI was legal because it derived from initial understanding and comprehension available in society. Therefore, the truth of fatwa is acceptable. The fatwa implies three matters, namely the necessity for developing anti-pluralism and promulticultural materials, the development of cultural-based da'wah strategy prioritizing social harmony, and treating differences by engaging in a dialogue and active tolerance for living together.
\end{abstract}

Keywords: Multicultural da'wah, MUI fatwa, Religious pluralism 


\section{Pendahuluan}

Keragaman budaya (multikultur) di Indonesia adalah sebuah realitas yang harus diterima dan disikapi dengan tepat. Dakwah sebagai upaya untuk mengajak, menyeru, dan memberikan anjuran dengan persuasif, ${ }^{1}$ dalam konteks Indonesia haruslah memperhatikan keragaman budaya masyarakat. Aktivitas dakwah di Indonesia mestilah berparadigma multikultural, yaitu paradigma dakwah yang concern pada penyampaian pesan dakwah dalam konteks masyarakat yang plural, dengan mengedepankan dialog untuk mencari kesepahaman dan kesepakatan bersama dari sekian banyak perbedaan. ${ }^{2}$ Pendekatan dakwah berbasis multikultural mencoba melihat keunikan dari yang banyak dan berbeda-beda dalam keragaman itu tidak harus dipaksa bersatu, tetapi tetap berjalan harmonis menjadi kesepahaman bersama dan bertoleransi. ${ }^{3}$ Oleh karenanya pelaksanaan dakwah multikultural selalu mengedepankan pendekatan yang ramah, bisa mengayomi, dialogis, dengan mempertimbangkan budaya-budaya masyarakat dan berpijak pada nilai universal kemanusiaan, tanpa mengubah maksud dan tujuan dakwah. ${ }^{4}$

Namun dalam praktiknya, kegiatan dakwah di Indonesia masih menghadapi kendala. Sebagian aktivis dakwah, baik individu maupun lembaga, masih menampakkan

\footnotetext{
1 M. Ali Aziz, Ilmu Dakwah Edisi Revisi, (Jakarta: Kencana Prenadamedia Grup, 2016), 17-18.

2 A. Ilyas Ismail dan Prio Hotman, Filsafat Dakwah: Rekayasa Membangun Agama dan Peradaban Islam (Jakarta: Kencana, 2011), 263-264.

3 lbid., 263.

4 Nawawi, "Dakwah dalam Masyarakat Multikultural," Komunika vol. 6, no. 1 (2012), pp.

${ }^{5}$ Rosidi, "Dakwah Multikultural di Indonesia: Studi Pemikiran dan Gerakan Dakwah Abdurrahman Wahid," Analisis vol. 13, no. 2 (2013): 482.
}

eksklusivitas dan egoisme. Dengan mengatasnamakan kebenaran, mereka melakukan tindak kekerasan, bahkan penyerangan terhadap kelompok yang berbeda pemikiran atau aliran. ${ }^{5}$ Munculnya kekerasan-kekerasan dalam kegiatan dakwah, ditengarai karena lemahnya kajiankajian keagamaan (dakwah) di umat Islam, karena landasan keilmuannya yang kurang kokoh, sehingga dakwah berjalan apa adanya tanpa ada desain yang teratur dan sistematis. $^{6}$ Untuk itu kesadaran dan penerimaan terhadap pluralitas dalam budaya dan agama masyarakat Indonesia penting untuk terus dikuatkan.

Sisi lain penerimaan pluralitas sebagai basis dakwah multikultural mendapatkan tantangan dari perdebatan pemikiran pluralisme agama. Kontroversi diametral antara agamawan dan akademisi terjadi pada masalah penerimaan pluralisme agama sebagai landasan etika sosial yang baik sebagai harmoni kehidupan sosial antarumat beragama ataukah pendangkalan akidah. $^{7}$

Plural yang berarti jamak, bukanlah istilah dalam tradisi Islam. Sebagian umat Islam dan aktivis dakwah bersedia menggunakan kata plural, pluralistik, atau pluralitas, tetapi menolak menggunakan istilah pluralisme. ${ }^{8}$ Sebab dalam pandangannya, plural adalah keragaman atau pengakuan terhadap

\footnotetext{
${ }^{6}$ Abdul Basit, Filsafat Dakwah (Jakarta: Rajagrafindo Persada, 2013), 15.

${ }^{7}$ Aris Kristianto, "Pluralisme Agama di Indonesia: Studi tentang Tipologi Pluralisme Agama Nonindifferent pada Keputusan Fatwa MUI Nomor 7 Tahun 2005" (Disertasi, UIN Sunan Ampel Surabaya, 2018), 3-5.

8 Zuly Qodir, "Pemikiran Islam, Multikulturalisme dan Kewargaan", dalam Wawan Gunawan Abd. Wahid, dkk, Fikih Kebinekaan: Pandangan Islam Indonesia tentang Umat, Kewargaan, dan Kepemimpinan Non-Muslim (Bandung: Mizan, 2015), 174-176.
} 
keragaman perbedaan. Sementara pluralisme berarti adalah paham atau aliran yang menerima kebenaran semua agama secara simile atau sejatinya berbeda tetapi dianggap sama. Definisi pluralisme yang semacam itu tentu membahayakan bagi keimanan seseorang. Oleh karenanya dalam dakwah mereka senantiasa menolak pluralisme teologis namun bersedia menerima pluralitas.

Definisi tersebut cukup beralasan mengingat John Hick, salah seorang tokoh pluralisme, menjelaskan bahwa fenomenologi sejarah agama-agama secara inheren menampakkan adanya fakta pluralisme teologis pada tradisi dan variasinya sehingga terdapat relasi antarbudaya dengan segala perbedaan dan komposisi klaimnya. Pandangan paradigmatisnya dengan memperlawankan tren inklusivisme dan eksklusivisme dalam beragama. Inklusivisme dalam beragama meyakini tradisi keagamaannya secara menyeluruh benar, tetapi parsialnya terefleksikan pada tradisi agama lain. Perkembangan lebih jauh dari inklusivisme yang mengakui adanya kebenaran di setiap tradisi agama dan kepercayaan ada pada pluralisme teologis. Sebaliknya, eksklusivisme dalam beragama meyakini tradisi partikular yang mengajarkan kebenaran dan mengandung jalan keselamatan dan pembebasan tidak pernah berubah. Artinya, keagamaan sendirilah yang benar dan selainnya salah. ${ }^{9}$

9 John Hick, "Religious Pluralism", dalam The Encyclopedia of Religion, ed. Mircea Eliade, et al. (New York: Simon \& Schuster Macmillan, 1995), 331.

10 Taslim H.M. Yasin, "Pluraslime Agama Sebuah Keniscayaan," Substantia: Jurnal IImu-IImu Ushuluddin, vol. 15 , no. 1 (2013):134-144.

${ }^{11}$ Abu Muhammad Waskito, Cukup 1 Gus Dur Saja! Sebuah Monumen Kontroversi, Kebodohan Sistemik
Gagasan awal pluralisme teologis menurut Parrinder dan Sharpe berasal dari tokohtokoh India, yaitu Rammohan Ray (17721833) awalnya penganut Hindu, kemudian mempelajari konsep-konsep Islam, dan menyimpulkan pemikiran Tuhan Yang Satu dan persamaan antaragama. Demikian pula tokoh mistis Bengali, Sri Ramakrishna (18341886), pengalaman mengarungi pengembaraan spiritual antaragama (passing over) dari Hindu ke Islam, kemudian Kristen kembali Hindu, menyimpulkan berbedanya agama bukanlah perbedaan yang berarti, karena hanya masalah ekspresi. ${ }^{10}$

Waskito melihat pluralisme dapat dipahami pada tataran praktis dan ideologis. Pluralisme secara praktis dapat diartikan sebagai sikap menerima dan menghargai perbedaan, dan toleransi, yang di dalam Islam disebut tasammuh 'alal ikhtilāf (sikap lapang dada dalam perbedaan pendapat). Sedang pluralisme dalam tataran ideologis merupakan konsep kesamaan dan kebenaran pada semua agama, perbedaannya hanya masalah interpretasi dan teknis. ${ }^{11}$

Pluralisme teologis ini selanjutnya memengaruhi makna agama bagi pemeluknya. Insersi kesadaran pada konsep pluralisme ini berimplikasi luas pada netralitas agama. Akibatnya memunculkan interpretasi dan kecurigaan semua pihak. ${ }^{12}$ Akibatnya, pelaksanaan dakwah multikultural yang bersinggungan dengan

dan Kerancuan Berfikir Bangsa (Jakarta: Pustaka AlKautsar, 2010), 113.

12 Syamsul Arifin, Merambah Jalan Baru dalam Beragama: Rekonstruksi Kearifan Perenial Agama Dalam Masyarakat Madani dan Pluralitas Bangsa (Yogyakarta: Ittaqa Press, 2001), 67. 
konsep pluralisme agama perlu memiliki landasan yang kukuh. Ketidakpahaman aktivis dakwah terhadap konsep pluralisme dapat mengakibatkan kekeliruan dalam dakwah multikultural. Ketika tidak bisa membedakan ragam tipologi pluralisme, aktivis dakwah bisa terjebak pada makna pluralisme agama yang samar, atau dibelokkan oleh pihak tertentu. Misalnya, pluralisme dalam arti teologis adalah penyatuan iman dari sekian perbedaan ajaran pada masing-masing agama bahkan identitas pemeluknya saling bertentangan menjadi terabaikan. Akibatnya dakwah pendekatan multikultural yang mencoba melihat perbedaan sebagai keunikan yang tidak harus dipaksakan untuk disatukan, menjadi pemaksaan terhadap pluralisme itu sendiri. Perbedaan dan keunikan agamaagama yang seharusnya dilindungi sebagai hak asasi manusia terpaksa melebur dalam bentuk pemahaman baru ajaran agama. Dalam beberapa kasus, pluralisme dijadikan alat untuk mendangkalkan akidah umat Islam seperti mengikuti tata cara ibadah agama lain. Menurut Abdusshomad Buchori (Ketua Majelis Ulama Indonesia Jawa Timur), banyak laporan informasi yang diterima MUI Jawa Timur. Beberapa Kiai turut hadir masuk gereja diundang Pendeta, yang itu dilakukan dengan alasan toleransi dan pluralisme. Oleh karenanya beliau menolak ketika Abdurrahman wahid (Gus Dur) dianugerahkan gelar "Bapak Pluralisme." Sebab menurutnya fenomena tersebut bisa membuat kerancuan pemahaman masyarakat awam, khususnya yang tidak memahami maksud pluralisme agama. ${ }^{13}$

13 "Dukung Pahlawan Nasional, MUI Jatim Tolak Gus Dur Bapak Pluralisme," nuonline, February 27, 2017. https://www.nu.or.id/post/read/21085/dukungpahlawan-nasional-mui-jatim-tolak-gus-dur-bapakpluralisme; Yunus, Mochammad. "MUI Jatim Tolak Gelar Bapak Pluralisme" Asshomadiyahcenter. April
Wacana pluralisme sebagai konsep interaksi antarumat beragama disikapi oleh Majelis Ulama Indonesia (MUI) dengan dikeluarkannya Fatwa MUI Nomor 7 Tahun 2005 tentang pluralisme, liberalisme, dan sekularisme agama. Rumusan fatwa yang dikeluarkan MUI melalui Munas VII Tahun 2005 menyebutkan, definisi pluralisme agama adalah paham yang mengajarkan semua agama sama, kebenarannya bersifat relatif sehingga setiap pemeluknya tidak boleh mengklaim hanya agama sendiri yang benar, sedangkan agama lain salah dan semua pemeluk akan masuk dan hidup berdampingan di surga. ${ }^{14}$ Kewenangan MUI mengeluarkan fatwa sebagai institusi keagamaan, layak untuk dijadikan landasan dalam pelaksanaan dakwah di Indonesia. Sebagaimana dalam penjelasannya, fatwa MUI tersebut menegaskan klaim kebenaran agama sendiri dibenarkan, sejauh tetap berkomitmen untuk saling menghargai dan mewujudkan keharmonisan sesama umat beragama. Menolak pluralisme dan menerima pluralitas dengan toleransi dan hidup damai berdampingan adalah sikap yang benar karena pluralitas adalah kemajemukan agama sebagai hukum sejarah. ${ }^{15}$

Keharaman pluralisme oleh Fatwa MUI bukannya tanpa penolakan. Beberapa kelompok yang pro pluralisme menolak asumsi dasar pluralisme yang dijadikan pijakan MUI. Kelompok propluralisme menolak pengertian pluralisme mengajarkan semua agama sama. Ulil Abshar Abdalla, berpendapat bahwa

19, 2014. http://asshomadiyahcenter.blogspot.com/2011/10/m ui-jatim-tolak-gelar-bapak-pluralisme.html

14 Ma'ruf Amin, Himpunan Fatwa Majelis Ulama Indonesia Sejak 1975, (Jakarta: Erlangga, 2011), 91. 15 Ibid., 95. 
pluralisme bukanlah undangan ke arah relativisme melainkan encounter of commitments, yaitu perjumpaan antarumat beragama yang beriman, berkomitmen mendalam atas tradisi agama masingmasing bukan menyamakan semua agama. ${ }^{16}$

Dengan demikian terdapat keragaman wacana pluralisme agama sehingga perlu kehati-hatian sikap bagi para aktivis dakwah. Dakwah berparadigma multikultural memang tidak boleh mengingkari adanya pluralitas (kemajemukan) dan mengembangkan pluralisme dalam tataran praktis, tanpa mereduksi iman. Misrawi menjelaskannya sebagai pluralisme yang hanya melihat aspek sosiologis, khususnya untuk memaksimalkan peran sosial bagi kelompok minoritas seperti toleransi, kesukarelaan, dan keadilan tanpa pretensi menggoyahkan iman. ${ }^{17}$

Dakwah multikultural yang berarti penyampaian pesan dakwah pada masyarakat yang plural dalam budaya dan agama, dengan mengedepankan dialog, toleransi, dan mencari titik temu dalam keragaman tidak boleh berakibat pada reduksi atau pendangkalan iman. Relasi pluralisme agama dalam tataran ideologi dapat merusak akidah manakala dijadikan pijakan dalam dakwah multikultural. Tujuan dakwah untuk memperkukuh keimanan malah akan tidak tercapai dengan asumsi pemahaman pluralisme yang keliru. Disinilah pentingnya landasan pemahaman dan hukum tentang pluralisme yang telah difatwakan oleh MUI. Perlu penegasan bahwa pluralisme tidak sama dengan multikultural. Dalam konteks sosial

16 Ulil Abshar Abdalla, "Pluralisme dan Pluralitas: Dua Sisi dari Koin Yang Sama," Islamlib.com, diakses 10 Mei 2016, www.Islamlib.com/author/ulil.htm.

17 Zuhairi Misrawi, "Rethinking Pluralisme Telaah Konsep dan Implementasi dalam kehidupan keagamaan penggunaan istilah ini mengandung konsekuensi yang berbeda. Sebagaimana pendapat Zuly Qodir kecenderungan penggunaan istilah pluralisme berkaitan dengan persoalan keagamaan (keimanan) dan multikulturalisme terkait masalah sosial budaya, dan politik. ${ }^{18}$

Fatwa MUI Nomor 7 Tahun 2005 merupakan respons $\mathrm{MUI}$ terhadap maraknya ajaran sekularisme, liberalisme, dan pluralisme agama, khususnya agama Islam. Sampai dengan studi ini dibuat, MUI belum melakukan perubahan atau revisi terkait fatwa tersebut. Polemik terkait fatwa tersebut berpusat pada pemaknaan pluralisme, yang sebagaimana disinggung di atas, tidak semua pihak sepakat dengan pemaknaan pluralisme oleh $\mathrm{MUI}$ sehingga menolak fatwa tersebut. Oleh karenanya, studi ini menganalisis lebih lanjut terkait makna pluralisme di Indonesia dalam fatwa tersebut, serta implikasinya dalam pelaksanaan dakwah multikultural.

Studi ini berangkat dari fenomena wacana pluralisme yang perlu disikapi dengan hatihati dalam pelaksanaan dakwah multikultural di Indonesia. Dengan demikian fokus masalah studi ini adalah: (1) bagaimana pluralisme agama menurut fatwa MUI yang menolak pluralisme dan menerima pluralitas sebagai landasan dakwah multikultural? apakah makna pluralisme dalam fatwa tersebut absah? (2) bagaimana implikasi fatwa tersebut terhadap penerapan dakwah multikultural di Indonesia? Tujuan dari studi ini adalah untuk

Sosioreligius di Indonesia," Dialogia Jurnal Studi Islam dan Sosial vol. 9, no. 1 (Juni 2011): 21.

18 Zuly Qodir, "Pemikiran Islam, Multikulturalisme dan Kewargaan," 185. 
mendeskripsikan fatwa MUI tentang pluralisme agama sebagai landasan dakwah multikultural dan implikasi pelaksanaannya di Indonesia. Secara praktis studi ini bermanfaat sebagai wawasan bagi para aktivis dakwah terkait fatwa MUI tentang pluralisme agama dan implikasinya terhadap pelaksanaan dakwah multikultural di Indonesia.

Studi-studi sebelumnya terkait fatwa MUI tentang pluralisme agama dan landasan dakwah multikultural, di antaranya adalah, pertama, skripsi berjudul "Analisis Fatwa MUI Tentang Pluralisme, Liberalisme, dan Sekularisme Agama." ${ }^{19}$ Skripsi tersebut bertujuan untuk memahami fatwa tersebut dan mengetahui perbedaannya dengan pemikiran Islam Liberal. Dengan metode hukum normatif tertulis sebagaimana fatwa, hasil penelitian menyimpulkan bahwa fatwa tersebut menegaskan pengharaman untuk mengikuti paham pluralisme, liberalisme, dan sekularisme. Perbedaan mencolok fatwa tersebut dengan pemikiran liberal yang membolehkan pluralisme, liberalisme, dan sekularisme adalah pada penekanan kebebasan berpikir, HAM, dan pengakuan kebenaran agama lain sebagai dasar mewujudkan toleransi dan proeksistensi kehidupan antarumat beragama. Sementara MUI mengakui pluralitas, bukan pluralisme, dengan toleransi dan kerukunan. Skripsi tersebut dengan studi ini sama-sama memahami fatwa MUI, hanya ruang lingkup dan orientasinya yang berbeda. Dalam studi ini ruang lingkupnya hanya pada fatwa pluralisme agama yang diorientasikan

19 Andi Permana, "Analisis Fatwa MUI Tentang Pluralisme, Liberalisme, dan Sekularisme Agama," (Skripsi, UIN Syarif Hidayatullah Jakarta, 2017).

20 Ilman Nafi'a, "Fatwa Pluralisme dan Pluralitas Agama MUI (Majelis Ulama Indonesia) Dalam Perspektif Tokoh Islam Cirebon," Holistik, vol. 14, no. 1 (2013): 125-150. sebagai landasan dakwah multikultural di Indonesia.

Kedua, artikel jurnal berjudul "Fatwa Pluralisme dan Pluralitas Agama MUI Dalam Perspektif Tokoh Islam Cirebon." ${ }^{20}$ Studi tersebut berangkat dari persoalan kontroversi fatwa MUI tentang keharaman pluralisme agama, termasuk di kalangan tokoh Islam Cirebon. Hasil studi menjelaskan bahwa ada sebagian yang memahami perbedaan antara pluralisme dan pluralitas, sehingga sebagaimana fatwa MUI mereka menolak pluralisme dan menerima pluralitas. Sebagian ada yang memahami bahwa antara pluralitas dan pluralisme memiliki pengertian yang sama, yaitu pengakuan atas kemajemukan atau keragaman agama. Oleh karenanya baik pluralitas maupun pluralisme tidak bermasalah. Kesamaan artikel tersebut dengan studi ini adalah pada ruang lingkup fatwa pluralisme agama, tetapi secara pendekatan dan orientasi berbeda.

Ketiga, artikel jurnal berjudul "Mengukur Kuasa Fikih dan Teologi atas Pemikiran: Studi Kasus Fatwa Pengharaman Liberalisme, Sekularisme, dan Pluralisme." ${ }^{21}$ Studi tersebut juga mempersoalkan fatwa MUI yang dikaji dalam studi ini. Di mana ismeisme yang dilarang dalam fatwa tersebut adalah bentuk kebebasan pemikiran di masyarakat. Dalam simpulannya menyebutkan bahwa reaksi konservatif dengan pendekatan fikih (fatwa MUI) dan teologis atas pemikiran bebas, seperti liberalisme, sekularisme, dan pluralisme,

21 Agus Ahmad Su'aidi, "Mengukur Kuasa Fikih dan Teologi atas Pemikiran: Studi Kasus Fatwa Pengharaman Liberalisme, Sekulerisme, dan Pluralisme," Ijtihad Jurnal Wacana Hukum Islam dan Kemanusiaan vol.10, no. 1 (Juni, 2010): 17-33. 
tidak menyelesaikan persoalan, bahkan merupakan alat yang salah. Sebagai gantinya studi tersebut menyarankan pengujian pemikiran secara dialektika ilmiah dan beradab. Sekalipun sama-sama membahas fatwa MUI, namun orientasi studi jelas berbeda. Artikel tersebut merespons keberadaan fatwa yang melarang pluralisme. Sementara studi ini mencoba memahaminya sebagai landasan dakwah multikultural.

Keempat, artikel berjudul "Islam Raḥmatan Li 'I-'Ālamīn sebagai Landasan Dakwah Multikultural: Perspektif Muhammad Fethullah Gülen."22 Tujuan artikel adalah untuk menganalisis konsep Fethullah Gülen mengenai raḥmatan li 'I-'alamin. Terdapat tiga temuan penting, pertama, Islam raḥmatan li 'I-'alamīn itu direfleksikan dengan cinta dan kasih. Kedua, Islam rahmatan li 'I-'alamīn itu direfleksikan dengan dialog antariman. Ketiga, Islam rahmatan li 'I-'alamīn itu direfleksikan dengan toleransi. Kesamaannya dengan studi ini adalah pada landasan dakwah multikultural. Jika studi ini mengkaji fatwa MUI tentang pluralisme agama sebagai landasan, artikel tersebut mengkaji pemikiran Islam rahmatan li Y'alamin Fethullah Gülen.

Signifikansi studi ini secara keseluruhan adalah melengkapi kajian terhadap fatwa MUI tentang pluralisme agama, sekaligus keabsahan makna pluralisme dalam fatwa tersebut, serta landasan dakwah multikultural. Yang mana sejauh

${ }^{22}$ Achmad Bisri, "Islam Raḥmatan Li 'I-'Ālamīn sebagai Landasan Dakwah Multikultural: Perspektif Muhammad Fethullah Gülen." Walisongo vol. 22, no. 02 (2014): 479-494.

23 Ismail Nawawi, Metode Penelitian Kualitatif, (Jakarta: Dwiputra Pustaka Jaya, 2012), 256-259. penelusuran studi ini, pengkajian fatwa MUI tentang pluralisme agama sebagai landasan dakwah multikultural masih belum dilakukan. Studi ini menggunakan metode kualitatif deskriptif, dengan subjek penelitian landasan dakwah multikultural dan objek penelitian fatwa MUI tentang pluralisme agama. Pendekatan utamanya studi pustaka, bersumber dokumen teks Fatwa MUI Nomor 7 Tahun 2005 tentang pluralisme, liberalisme dan sekularisme agama; Buku Himpunan Fatwa Majelis Ulama Indonesia (MUI) Sejak 1975, yang tidak hanya berisi himpunan fatwa tetapi juga tentang fatwa dan prosedur menetapkan fatwa di MUI; buku-buku dan artikel jurnal terkait yang membahas masalah pluralisme agama. Kerangka konseptual merujuk pada konsep pluralisme agama, kelembagaan MUI, dan karakteristik dakwah multikultural. Analisis data dilakukan secara kualitatif mengikuti model Miles dan Huberman yaitu mulai reduksi data (pemilahan data), penyajian data, dan penarikan kesimpulan. ${ }^{23}$

\section{Pluralisme Agama}

Kata "pluralisme" terdiri dari kata dasar "plural" artinya (form of a word) used of referring to more than one, jamak (lebih dari satu), ${ }^{24}$ "isme" yang berarti "sistem kepercayaan berdasarkan politik, sosial, atau ekonomi. ${ }^{25}$ Sehingga pluralisme secara kebahasaan adalah sistem kepercayaan terhadap realitas yang jamak. Dalam filsafat, pluralisme adalah konsep yang menjelaskan

\footnotetext{
24 Departemen Pendidikan dan Kebudayaan, Kamus Besar Bahasa Indonesia, Edisi Il (Jakarta: Balai Pustaka, 1994), 884.

25 Kamus Besar Bahasa Indonesia, Offline Versi 1.1, 2010.
} 
bahwa realitas subtantif tidak monisme dan tidak pula dualisme melainkan beragam. ${ }^{26}$

Keterlibatan agama dalam pluralisme berasal dari asumsi pendekatan ilmu sosial bahwa pluralisme agama sebagai kerangka interaksi antarkelompok yang saling menghormati secara koeksistensi, yaitu hidup bersama tanpa konflik. Sebagaimana pengertian dan gagasan pluralisme menurut Farid Esack adalah pengakuan dan penerimaan tentang keberbedaan dan keragaman lebih dari sekadar toleransi. Ada unsur penerimaan cara dalam menanggapi dorongan pada sesuatu yang transenden. ${ }^{27}$ Sementara John Hick secara fenomenologi melihat pluralisme agama merujuk kepada fakta sejarah agama-agama menunjukkan pluralitas tradisi dan variasi di setiap bagiannya. Pluralisme agama merupakan perkembangan lebih jauh dari inklusivisme yang mengakui adanya kebenaran di setiap tradisi agama dan kepercayaan. ${ }^{28}$

Berbagai pemaknaan pluralisme dikategorikan dalam dua pendekatan, yaitu teologi dan sosiologi. Pluralisme perspektif sosiologi merupakan masalah politik daripada agama. Konsep pluralisme berdasarkan identifikasi tren pemikiran menurut Anis Malik Thoha ada empat tren pemikiran agama, pertama, humanisme sekular, yaitu mewujudkan koeksistensi damai (peacefull co-existence) antaragama. Sentralitas manusia sebagai subjek (antroposentris) gagasan William James dan sekularisme sebagai asas koeksistensi damai antaragama yang direpresentasikan tokoh

26 Paul Edwards, The Encyclopedia of Philosophy, Volume 5 (New York: Mac Milan Publishing, 1967), 363-364.

27 Farid Esack, Qur'an, Liberation and Pluralism: An Islamic Perspective of Interreligious politik seperti Benjamin Franklin dan teolog seperti Havey Cox. Kedua, teologi global (global theology), yaitu pluralisme agama yang merujuk pada rekonsepsi agama gagasan Wilfred Cantwel Smith dan hipotesis transformasi pemusatan diri menuju Yang Maha Nyata (The Real) oleh John Hick. Meskipun memiliki perbedaan pandangan dan jalan tentang The Ultimate Reality (Tuhan) dalam berbagai agama, hakikatnya menuju keselamatan yang sama. Ketiga, sinkretisme, yaitu perpaduan gagasan kebenaran dalam berbagai agama secara teologis yang saling melengkapi. Keempat, hikmah abadi (perenial philosophy, shophia perenis). Istilah Ibnu Khaldun, al-Hikmah al-Khālidah, yaitu pluralisme yang berpijak pada keyakinan untuk membedakan antara kebenaran dan keberadaan/kenyataan. Jika kebenaran disebut hakikat transenden (transcendent reality) adalah yang satu dan tidak mungkin diketahui, maka kenyataan disebut hakikat keagamaan (religious reality) sebagai manifestasi eksternal yang beragam dari hakikat transenden tersebut. ${ }^{29}$

Dari berbagai konsep menunjukkan teori pluralisme beragam dan kompleks, namun terklasifikasikan dua faktor, pertama, faktor internal (ideologis), akibat tuntunan agama pada kebenaran mutlak mengenai akidah, doktrin dan sejarah. Sikap absolutisme agama yang wajar tanpa pertentangan ini memunculkan teori relativisme agama sebagai pluralisme agama. Said Agil Husin Al Munawar menyebutkan, sejarah telah

Solidarity Against Oppression (England: Oneworld Publication, 1997), xii.

28 John Hick, "Religious Pluralism", dalam The Encyclopedia of Religion, 337.

${ }^{29}$ Anis Malik Thoha, Trend Pluralisme Agama: Tinjauan Kritis (Jakarta: Perspektif, 2006), 41-42. 
membuktikan tidak ada agama yang tidak melakukan klaim kebenaran mutlak. ${ }^{30}$

Kedua, faktor eksternal, meliputi (a) faktor sosio-politis. Pengembangan wacana sosiopolitis, demokratis, dan nasionalisme melahirkan sistem negara bangsa ke arah globalisasi selama tiga abad. Pasca pemikiran liberalisme pengusung gagasan kebebasan, toleransi, kesamaan, dan pluralisme. Liberalisme tidak lagi terbatas masalah politis bahkan politisasi dan intervensi agama secara sistematis. Liberalisme memainkan watak universal dan komprehensifnya pada HAM sehingga hak beragama dan berkeyakinan menjadi turut serta. Akibatnya, agama disubordinasikan pada kekuatan sistem di luar agama hingga melupakan realitas agama; ${ }^{31}$ (b) faktor keilmuan modern. Perkembangan studi perbandingan agama-agama dunia mensyaratkan perdamaian tanpa mempersoalkan perbedaan keyakinan. Evolusi politik dan ekonomi juga melahirkan evolusi sosial budaya yang saling memengaruhi. ${ }^{32}$

Ajaran Islam sendiri mengakui perbedaan sebagai gejala sosial dan keagamaan universal tanpa dipengaruhi oleh sejarah perang antaragama atau misi genosida baik etnik, keagamaan, dan pemusnahan peradaban. Pandangan tersebut merupakan cerminan ayat Al-Qur'an mengenai kebebasan memilih agama dan tugas pengabdian kepada Tuhan tanpa intervensi atau paksaan. Beribadah kepada Allah, Tuhan Pencipta alam semesta sebagai

30 Said Agil Husin Al Munawar, Fikih Hubungan Antar Agama (Jakarta: Ciputat Press, 2003), 207.

${ }^{31}$ Anis Malik Thoha, Trend Pluralisme Agama, 41-42.

32 Ibid., 43. tujuan tidak diraih melalui pengingkaran melainkan pengakuan terhadap perbedaan sebagai konsekuensi atas keragaman dan kesatuan dalam pluralisme. Interaksi antarumat beragama melalui mekanisme dialog dan kerja sama dalam kebaikan dengan mengakui sepenuhnya hak-hak orang lain untuk berbeda sekaligus menolak paksaan untuk konversi iman. ${ }^{33}$

\section{Karakteristik Dakwah Multikultural}

Multikultural sebagai keanekaragaman budaya termasuk bahasa, agama, adat istiadat, dan pola tatanan perilaku anggota masyarakatnya. Multikultural membangun nilai keragaman dan perbedaan budaya antarkelompok masyarakat dalam mengekspresikan kebudayaan agar saling menghormati tanpa prasangka buruk dan permusuhan. $^{34}$

Kesadaran pada realitas dan kondisi masyarakat yang heterogen serta makin mengglobal, membuat perlunya pendekatan dakwah yang bercorak multikultural. Dakwah multikultural melihat bahwa perbedaan muslim dan nonmuslim sebagai objek dakwah adalah keunikan yang tidak harus dipaksakan untuk disatukan, tetapi bagaimana tetap bisa berjalan secara harmonis, sehingga dakwah multikultural fokus pada penyampaian pesan dakwah yang mengedepankan dialog, bukan pemaksaan, serta tetap menjaga kerukunan dan toleransi. ${ }^{35}$ Dakwah multikultural

33 Sheikh Rashid Ghanoushi, "Pluralisme dan Monoteisme dalam Islam", dalam Mansoor al-Jamri (ed.), Islamisme, Pluralisme dan Civil Society, 66-67.

${ }^{34}$ Willy Kimlicka, Kewargaan Multikultural (Jakarta: LP3ES, 2003), 12

35 Ibid., 263. 
memiliki kekhasan yang berbeda dengan dakwah konvensional. Ismail dan Hotman menjelaskan empat ciri dakwah multikultural, yaitu pertama, mengakui sekaligus menghargai etno-religio pada keunikan dan keragaman ini berbeda dengan relativisme apalagi sinkretisme. Keragaman budaya dan keyakinan adalah fakta bukan masalah, sehingga harus diterima. Kedua, mengakui adanya titik kesamaan dalam keragaman etno-religio. Dalam keanekaragaman budaya dan kayakinan terdapat nilai-nilai bersama(universal) yang dapat menjadi titik temu dalam membangun relasi sosial, juga menerima adanya aspek-aspek yang tidak mungkin dikompromikan. Terhadap adanya perbedaan perlu dilakukan pengelolaan untuk belajar hidup di dalamnya. Ketiga, pendekatan multikultural mencoba memahami tingkah laku umat beragama (mad'uw) sebagai fenomena kultur, sehingga perbedaan-perbedaan keyakinan dibingkai dalam konsep budaya toleransi, kerja sama, dan harmoni sosial. Keempat, kemestian progresif dan dinamis dalam memahami agama. Bahwa setiap kebudayaan agama adalah sebuah proses yang tumbuh dan berkembang secara berkelanjutan, sejalan dengan pemahaman dan penghayatan terhadap agama. ${ }^{36}$

Ismail dan Hotman mengusulkan beberapa prinsip pendekatan dakwah multikultural, yaitu pertama, menekankan agar target dakwah lebih diarahkan pada pemberdayaan kualitas umat dalam ranah internal, kerja sama, serta dialog antaragama dan budaya dalam ranah

36 Ismail dan Hotman, Filsafat Dakwah: Rekayasa Membangun Agama dan Peradaban Islam (Jakarta: Kencana, 2011), 264-267.

37 Ibid. eksternal. Berbeda dengan pendekatan konvensional, pendekatan dakwah multikultural menilai fenomena konversi nonmuslim menjadi muslim bukan tujuan utama dari dakwah itu sendiri melainkan efek samping dari tujuan dakwah. Kedua, dakwah multikultural sebagai kebijakan publik dan politik, menggagas ide tentang kesetaraan hak-hak warga negara (civil right), termasuk kelompok minoritas. Ketiga, dakwah multikultural dalam dimensi sosial memilih untuk mengambil pendekatan kultural ketimbang harakah (gerakan). Keempat, dakwah multikultural konteks pergaulan global, menggagas ide dialog antarbudaya dan keyakinan (intercultur-faith understanding). Kelima, perlunya penyegaran kembali pemahaman doktrindoktrin Islam klasik melalui reinterpretasi dan rekonstruksi paham keagamaan sesuai perkembangan masyarakat globalmultikultural. ${ }^{37}$

Dakwah multikultural yang dikembangkan dari konsep multikulturalisme, yaitu paham asas keragaman suatu bangsa tentang penataan sosial budaya secara egaliter akibat diskriminasi sosial dan budaya terhadap kelompok minoritas, ${ }^{38}$ disalahartikan atau dikesankan identik dengan pluralisme agama yang merujuk pada kesamaan dan penyatuan dari keragaman keyakinan agama. Akibatnya, penggunaan istilah pluralisme bagi pemeluk agama-agama cukup sensitif di masyarakat sehingga MUI mengeluarkan fatwa terkait hal tersebut. Pemahaman Fakta dan Gejala Permasalahan Sosial: Teori, Aplikasi, dan Pemecahannya (Jakarta: Kencana Prenada Media, 2011), 554. 


\section{Kelembagaan dan Fatwa MUI}

MUI bukanlah lembaga pemerintahan, juga bukan merupakan organisasi masyarakat atau partai politik. Dengan demikian MUI tidak memiliki keanggotaan sebagaimana ormas atau parpol. Pengurus MUI terdiri atas para ulama dan cendekiawan muslim yang dipandang bisa merepresentasikan ormas-ormas Islam yang ada di Indonesia. Namun tetap MUI bukanlah perkumpulan atau perhimpunan ormas-ormas Islam tersebut, melainkan organisasi atau lembaga yang bersifat forum. ${ }^{39}$ Sehingga secara struktural tidak ada hubungan dengan ormas-ormas Islam, sekalipun ada ulamanya yang menjadi pengurus $\mathrm{MUI}$, namun lebih bersifat pribadi. ${ }^{40}$ Artinya seorang ulama atau cendekiawan menjadi pengurus MUI adalah karena kapabilitasnya, serta dipandang bisa mewakili ormasnya. Oleh sebab itu, keberadaan MUI memiliki signifikansi sebagai forum kolektif kepemimpinan umat Islam, sekaligus sebagai jembatan ukhuwah dan silaturahmi umat Islam Indonesia.

Mudzhar mengungkapkan beberapa ciri umum terkait keberadaan dan peran kelembagaan MUI, yaitu: (1) keberadaan lembaga MUI dapat diterima dengan baik oleh organisasi-organisasi Islam dan umat Islam Indonesia pada umumnya; (2) MUI senantiasa berupaya menjaga hubungan yang baik dengan berbagai elemen masyarakat dan pemerintah; (3) terkait untuk menjaga akidah kaum muslim, MUI

39 Ainul Yaqin, Menolak Liberalisme Islam: Catatan Atas Berbagai Wacana dan Isu Kontemporer. (Surabaya: Majelis Ulama Indonesia Provinsi Jawa Timur, 2012), 225.

40 Badan Litbang Agama dan Diklat Keagamaan Departemen Agama RI, Fatwa Majelis Ulama Indonesia (MUI) dalam Perspektif Hukum dan Perundang-undangan (Jakarta: Puslitbang Lektur dan bersikap waspada terhadap ancaman, ${ }^{41}$ khususnya konteks usaha golongan lain yang melakukan konversi iman, terlebih dengan meluasnya pemikiran pluralisme agama.

Adapun tugas MUI adalah memberikan fatwa dan nasihat untuk umat Islam dan pemerintahan Indonesia terkait persoalanpersoalan keagamaan dan kebangsaan secara umum. Selain itu diharapkan MUI juga bisa mendorong persatuan umat muslim Indonesia, menjadi penengah apabila terdapat perbedaan antara misalnya pemerintah dan kaum ulama. MUI juga bertugas menjadi wakil atau utusan dalam musyawarah dan dialog antargolongan agama di Indonesia. ${ }^{42}$ Secara fungsional MUI memiliki empat fungsi, yaitu: (1) menjadi wadah dialog dan musyawarah para ulama, $z u^{\prime} a m \bar{a}^{\prime}$ dan cendekiawan Islam guna membicarakan problematika keumatan dan kebangsaan, (2) menjadi wadah silaturahmi dan membangun ukhuwah Islamiyah; (3) sebagai representasi umat Islam dalam hubungannya dengan konsultasi dan komunikasi antarumat yang berbeda agama di Indonesia; (4) memberikan dan mengeluarkan fatwa yang ditujukan untuk umat Islam Indonesia dan pemerintahan, baik ketika diminta maupun tidak. ${ }^{43}$

Keberadaan MUI lekat dengan fatwa. Dalam tinjauan etimologis, fatwa berarti jawaban hukum yang dikeluarkan oleh mufti untuk suatu permasalahan yang dimintakan kepadanya. Dalam tinjauan terminologi, menurut Yusuf Qardhawi, fatwa merupakan

Khazanah Keagamaan Badan Litbang dan Diklat Kemenrian Agama RI, 2012), 94.

41 Mohammad Atho Mudzhar, Fatwa-Fatwa Majelis Ulama Indonesia: Sebuah Studi Tentang Pemikiran Hukum Islam di Indonesia 1975-1988 (Jakarta: INIS, 1993), 79.

42 Ibid., 63.

43 Ibid., 38-40. 
penerangan hukum syara' terkait persoalan tertentu, yang menjadi jawaban atas pertanyaan yang diajukan oleh peminta fatwa. ${ }^{44}$ Dengan demikian fatwa terkait penjelasan status hukum peristiwa tertentu yang menjadi masalah atau pertanyaan, yang jawabannya melandaskan pada dalildalil. Pengertian tersebut sejalan dengan Pedoman dan Prosedur Penetapan Fatwa MUI yang menuliskan bahwa fatwa merupakan jawaban atau penjelasan masalah keagamaan dari ulama yang berlaku secara umum. ${ }^{45}$ Jawaban resmi atas pertanyaan dan persoalan terkait dogma atau hukum Islam mensyaratkan keberadaan otoritas yang kredibel dalam memberikan fatwa (al-ijāzahli al-iftā') yang itu berada pada penerimaan secara luas akan kapabilitas seseorang oleh dewan ahli hukum terkemuka. Aktivitas penetapan fatwa tersebut dilakukan secara kolektif oleh suatu lembaga yang dinamakan Komisi Fatwa. ${ }^{46}$ Komisi Fatwa terdiri atas orangorang dengan kompetensi mengeluarkan fatwa terkait persoalan umum yang berhubungan dengan fikih, serta kebenaran akidah. ${ }^{47}$

Dalam menetapkan fatwa terdapat dasardasar metodologis yang dikenal dengan istinbat hukum. Istinbat hukum yang menjadi landasan MUI diatur dalam keputusan MUI Nomor: U-596/MUI/X/1997 tanggal 2 Oktober 1997, yang isinya adalah berikut: (a) landasan dasar fatwa meliputi AlQur'an, sunah yaitu perilaku, tradisi dan kebiasaan nabi, ijmak yaitu kesepakatan pendapat di antara ulama-ulama, qiyās yaitu penyimpulan dengan analogi;

44 Yusuf Qardawi, Fiqh Prioritas, (Mansyurat Kuliah Da'wah Islamiyah, 1990), 203.

45 Amin, Himpunan Fatwa Majelis Ulama Indonesia Sejak 1975, 5. Fatwa adalah bentuk tunggal. Sedangkan bentuk jamaknya adalah fatāwō. perbincangan suatu masalah yang dipandang membutuhkan fatwa diharuskan melandaskan pada pertimbangan dasardasar fatwa, pendapat para imam mahzab, pendapat para ulama terkemuka yang diperoleh dengan jalan penelitian penafsiran Al-Qur'an; (c) pembahasan yang merujuk ke atas adalah metode penafsiran terkuat dan dipandang bermanfaat bagi umat Islam; (d) Jika suatu masalah yang membutuhkan fatwa tidak bisa dilaksanakan secara prosedural, maka harus diputuskan dengan penafsiran dan pertimbangan ijtihad; (e) otoritas dan cakupan fatwa MUI terkait persoalan keagamaan dan kemasyarakatan umat Islam Indonesia secara umum. Persoalan keagamaan yang sekira relevan dengan wilayah tertentu dapat pula ditetapkan untuk wilayah lain; (f) Sidang Komisi Fatwa harus diikuti anggota komisi yang telah diangkat oleh pimpinan pusat MUI dan pimpinan pusat MUI provinsi, serta bila diperlukan dapat mengundang para ahli; (g) Sidang Komisi Fatwa harus dilaksanakan saat ada kebutuhan dan atau permintaan yang dipandang MUI secara kelembagaan memerlukan fatwa. Permintaan tersebut dapat berasal dari masyarakat, lembaga sosial, pemerintah, maupun MUI sendiri; (h) sejalan dengan aturan Sidang Komisi Fatwa bahwa bentuk fatwa untuk persoalan tertentu harus diserahkan kepada Ketua MUI nasional dan provinsi; (i) pimpinan pusat MUI nasional/provinsi akan merumuskan kembali fatwa tersebut menjadi bentuk Sertifikat Keputusan Penetapan Fatwa ${ }^{48}$ Sudah tentu dasar-dasar dan prosedur penetapan fatwa dalam keputusan MUI tersebut untuk masalah-

46 Ibid.

47 Yaqin, Menolak Liberalisme Islam, 226.

48 M.B. Hooker, Islam Mazhab Indonesia: Fatwa-fatwa dan Perubahan Sosial, trans. Iding Rosyidin Hasan (Jakarta: Teraju, 2002), 93-94. 
masalah diluar persoalan keimanan dan syariat (ibadah) memungkinkan untuk berbeda sehingga membutuhkan banyak interpretasi dalam mencari solusi.

\section{Penjelasan Fatwa MUI Nomor 7 Tahun 2005}

\section{Latar Belakang dan Tujuan}

MUI secara moral memiliki tanggung jawab untuk melindungi kaum muslim Indonesia dari beragam serangan dan praktik-praktik kemungkaran. Oleh karenanya dalam persoalan akidah perlu dijawab dalam sebuah fatwa bukan sekadar secara lisan sebagai nasihat atau rekomendasi. Maka sebagai upaya untuk melindungi dan menjaga umat Islam dari ajaran yang menyimpang, MUI merasa perlu untuk mengeluarkan fatwa terkait larangan atau tidak bolehnya mengikuti ajaran liberalisme, sekularisme, dan pluralisme agama yang tertuang dalam putusan Fatwa MUI Nomor 7 Tahun 2005. ${ }^{49}$

Fatwa tersebut adalah respon ulama dalam persoalan akidah serta ibadah, yang diajukan oleh penanya atau peminta fatwa sehubungan dengan adanya pranatapranata sosial yang terus berkembang di masyarakat yang menunjukkan signifikansi pengaruhnya. Pada Bab VI Pedoman dan Prosedur Penetapan Fatwa MUI disebutkan bahwa MUI memiliki wewenang menetapkan fatwa terkait persoalanpersoalan keagamaan, khususnya persoalan hukum/fikih dan akidah yang berhubungan dengan kemurnian dan kebenaran keimanan umat Islam di Indonesia. ${ }^{50}$

49 Yaqin, Menolak Liberalisme Islam, 18.

50 Ibid., 7.
Pada tanggal 26-29 Juli $2005 \mathrm{M}$ atau 19-22 Jumadil Akhir $1426 \quad$ H dilaksanakan Musyawarah Nasional (Munas) ke-VII MUI. Dalam Munas tersebut, Komisi Fatwa yang dipimpin oleh K.H. Ma'ruf Amin menetapkan sebelas keputusan fatwa, yang salah satunya adalah mengharamkan pluralisme (pandangan yang menganggap semua agama sama), liberalisme, dan sekularisme. Keluarnya fatwa tersebut tidak bisa dipisahkan dengan konteks global dan lokal. Maraknya pemikiran dan gerakan yang mengunggulkan pluralisme, serta liberalisme sebagai ajaran atau paham baru sangatlah meresahkan. Ada kekhawatiran apabila ajaran tersebut diikuti maka akan menjauhkan umat dari agamanya sendiri, kehilangan jati diri, dan identitas keberagamaannya, dan akhirnya meragukan kebenaran ajaran Islam itu sendiri karena berpikiran bahwa semua agama benar. ${ }^{51}$ Pada level global terdapat desakan-desakan dari beberapa negara guna menciptakan tatanan kehidupan kedamaian di dunia lewat dialog intensif dan keterbukaan antaragama. Di antaranya adalah dengan membentuk dan menyelenggarakan forumforum dan organisasi nonpemerintahan yang secara khusus menyebarkan dan mempromosikan pluralisme di masyarakat dunia. $^{52}$

Keluarnya fatwa tersebut dinilai oleh sebagian kalangan sebagai bentuk tanggung jawab MUI dalam membentengi akidah kaum muslim Indonesia. Hal tersebut terlihat dalam konsideran fatwa pada bagian pertimbangan yang berisi latar belakang, alasan, dan pentingnya ketetapan fatwa

\footnotetext{
51 Imam Subkhan. Hiruk Pikuk Wacana Pluralisme di Yogya: City of Tolerance (Yogyakarta: Impulse dan Kanisius, 2007), 30.

52 Ibid., 31.
} 
tersebut, ${ }^{53}$ yaitu: Pertama, keberadaan fatwa MUI Nomor 7 Tahun 2005 adalah terkait perkembangan ajaran liberalisme, sekularisme, dan pluralisme. Kedua, ajaranajaran tersebut telah meresahkan dan membingungkan masyarakat Islam di Indonesia, oleh karenanya mereka meminta MUI untuk mengeluarkan fatwa terkait masalah tersebut. Ketiga, MUI menilai perlunya menetapkan fatwa terkait persoalan liberalisme, sekularisme, dan pluralisme agama untuk menjawab kebutuhan dan dapat dijadikan petunjuk bagi umat Islam Indonesia. ${ }^{54}$

\section{Dasar Hukum Fatwa}

Pada bagian mengingat dalam konsideran fatwa MUI berisi tentang dasar-dasar hukum (adillahal-ahkam) yang dijadikan pijakan oleh Komisi Fatwa MUI. ${ }^{55}$ Secara keseluruhan terdapat dua sumber yang menjadi pijakan, yaitu ${ }^{56}$ pertama, firman Allah SWT pada surah dan ayat, sebagaimana dalam tabel berikut:

Tabel 1 - Ayat Al-Qur'an yang Menjadi Landasan Fatwa MUI

\begin{tabular}{|c|c|c|c|}
\hline No & Surah & Ayat & Isi (Terjemah) \\
\hline 1 & Ali Imran & 85 & $\begin{array}{l}\text { "Barangsiapa mencari agama selain agama Islam, maka sekali-kali tidaklah } \\
\text { akan diterima (agama itu) daripadanya, dan dia di akhirat termasuk orang- } \\
\text { orang yang rugi." } 57\end{array}$ \\
\hline 2 & Ali Imran & 19 & "Sesungguhnya agama (yang diridai) di sisi Allah hanyalah Islam...."58 \\
\hline 3 & Al-Kafirun & 6 & "Untukmulah agamamu, dan untukkulah agamaku." \\
\hline 4 & Al-Ahzab & 36 & $\begin{array}{l}\text { "Dan tidaklah patut bagi laki-laki yang mukmin dan tidak (pula) bagi } \\
\text { perempuan yang mukmin, apabila Allah dan Rasul-Nya telah menetapkan } \\
\text { suatu ketetapan, akan ada bagi mereka pilihan (yang lain) tentang urusan } \\
\text { mereka. Dan barangsiapa mendurhakai Allah dan Rasul-Nya maka } \\
\text { sungguhlah dia telah sesat, sesat yang nyata."60 }\end{array}$ \\
\hline 5 & $\begin{array}{l}\text { Al- } \\
\text { Mumtahana } \\
\text { h }\end{array}$ & $8-9$ & $\begin{array}{l}\text { Allah tiada melarang kamu untuk berbuat baik dan berlaku adil terhadap } \\
\text { orang-orang yang tiada memerangimu karena agama dan tidak (pula) } \\
\text { mengusir kamu dari negerimu. Sesungguhnya Allah menyukai orang-orang } \\
\text { yang berlaku adil. Sesungguhnya Allah hanya melarang kamu menjadikan } \\
\text { sebagai kawanmu orang-orang yang memerangi kamu karena agama dan } \\
\text { mengusir kamu dari negerimu dan membantu (orang lain) untuk } \\
\text { mengusirmu. Dan barangsiapa menjadikan mereka sebagai kawan, maka } \\
\text { mereka itulah orang-orang yang zalim. }{ }^{61}\end{array}$ \\
\hline 6 & An-Naml & 77 & $\begin{array}{l}\text { Dan carilah pada apa yang telah dianugerahkan Allah kepadamu } \\
\text { (kebahagiaan) negeri akhirat, dan janganlah kamu melupakan bahagianmu } \\
\text { dari (kenikmatan) duniawi dan berbuat baiklah (kepada orang lain) } \\
\text { sebagaimana Allah telah berbuat baik kepadamu, dan janganlah kamu } \\
\text { berbuat kerusakan di (muka) bumi. Sesungguhnya Allah tidak menyukai } \\
\text { orang-orang yang berbuat kerusakan. }{ }^{62}\end{array}$ \\
\hline
\end{tabular}

\footnotetext{
${ }^{53}$ Amin, Himpunan Fatwa Majelis Ulama Indonesia, $7 . \quad 58$ Ibid., 65.

$54 \mathrm{lbid}$., 87.

55 Ibid., 90.

56 Ibid., 88-90. $\quad{ }^{61} \mathrm{lbid} ., 803$.

57 Departemen Agama R.I., Al-Qur'an dan Terjemahnya $\quad 62$ lbid., 556.
}

Juz 1-30 (Surabaya: Karya Agung, 2006), 76. 


\begin{tabular}{cccc}
\hline No & Surah & Ayat & \multicolumn{1}{c}{ Isi (Terjemah) } \\
\hline 7 & Al-An'aam & 116 & $\begin{array}{l}\text { Dan jika kamu menuruti kebanyakan orang-orang yang di muka bumi ini, } \\
\text { niscaya mereka akan menyesatkanmu dari jalan Allah. Mereka tidak lain } \\
\text { hanyalah mengikuti persangkaan belaka, dan mereka tidak lain hanyalah } \\
\text { berdusta (terhadap Allah). }\end{array}$ \\
8 & $\begin{array}{l}\text { Al- } \\
\text { Mukminuun }\end{array}$ & 71 & $\begin{array}{l}\text { Andaikata kebenaran itu menuruti hawa nafsu mereka, pasti binasalah langit } \\
\text { dan bumi ini, dan semua yang ada di dalamnya. Sebenarnya Kami telah } \\
\text { mendatangkan kepada mereka kebanggaan mereka tetapi mereka berpaling } \\
\text { dari kebanggaan itu. }\end{array}$ \\
\hline
\end{tabular}

Kedua, hadis Nabi saw. yang diriwayatkan oleh Imam Muslim, tertulis dalam Shahih Muslim: "Demi Dzat Yang menguasai jiwa Muhammad, tidak ada seorang pun baik Yahudi maupun Nasrani yang mendengar tentang diriku dari umat Islam ini, kemudian ia mati dan tidak beriman terhadap ajaran yang aku bawa, kecuali ia akan menjadi penghuni neraka."65 Dalam Shahih Muslim dan Bukhari juga diriwayatkan bahwa Nabi pernah menulis dan mengirimkan suratsurat kepada pada raja-raja nonmuslim, seperti Raja Najasyi di Abesenia yang beragama Nasrani, Kaisar Heraklius di Romawi yang juga beragama Nasrani, Raja atau Kisra Persia yang memeluk Majusi. Dalam surat-suratnya Nabi mengajak mereka agar memeluk ajaran Islam yang dibawanya. ${ }^{66}$ Selain itu dalam pergaulan sosialnya, Nabi saw. juga menjalin hubungan sosial dengan kelompok-kelompok nonmuslim, termasuk komunitas Yahudi di Madinah, di Khaibar, dan kaum Nasrani di Najran.

\section{Ketetapan Hukum Fatwa MUI}

Pertama, dalam ketentuan umum Fatwa MUI Nomor 7 Tahun 2005 dijelaskan bahwa pluralisme agama merupakan ajaran atau paham yang meyakini bahwa semua agama adalah sama, sehingga kebenaran agama bersifat relatif. Implikasinya maka pemeluk agama tidak diperkenankan mengklaim hanya agamanya sajalah yang benar sedangkan yang lainnya salah. Pluralisme agama juga berpendapat bahwa semua agamawan kelak akan bersama-sama hidup di surga. Pengertian tersebut berbeda dengan pluralitas yang berarti realitas sosial adanya keragaman berbagai pemeluk agama di wilayah tertentu yang hidup bersama dan berdampingan. ${ }^{67}$

Kedua, ketentuan hukum. Pluralisme agama sebagaimana dijelaskan di atas adalah ajaran atau paham yang tidak terdapat dan bertentangan dengan Islam. Oleh karenanya umat Islam diharamkan meyakini dan mengikuti paham pluralisme agama. Hal tersebut menyangkut masalah akidah dan ibadah, yang mana menurut MUI, umat Islam harus memiliki sikap eksklusif. Dalam arti tidak diperkenankan dan diharamkan untuk mencampuradukkan masalah akidah dan ibadah dengan ajaran agama lain. Ajaran pluralisme agama sudah menyangkut masalah akidah dan ibadah. Sementara bagi umat Islam yang hidup dan tinggal dengan pemeluk agama lain diperlukan sikap inklusif

\footnotetext{
63 Ibid., 192.

64 Ibid., 482.

65 Hadits Riwayat, Muslim.

${ }^{66}$ Ibid., Ibn Sa'd dalam al-Thabaqat al-Kubra dan Imam al-Bukhari dalam Shahih al-Bukhari.

${ }^{67}$ Amin, Himpunan Fatwa Majelis Ulama Indonesia, 91.
} 
untuk masalah-masalah sosial yang tidak berhubungan dengan akidah dan ibadah, sehingga tetap melakukan pergaulan sosial dengan prinsip saling menghormati dan tidak saling merugikan. ${ }^{68}$

\section{Penjelasan Fatwa MUI Nomor 7 Tahun 2005}

Dalam bagian penjelasan Fatwa MUI Nomor 7 Tahun 2005, terkait keharaman pluralisme agama, antara lain: ${ }^{69}$ pertama, masyarakat Islam Indonesia saat ini tengah menghadapi serangan pemikiran (ghazwul fikr) di antaranya adalah dengan masuknya paham pluralisme agama. Serangan pemikiran tersebut membawa implikasi pada kepercayaan dan keberagamaan umat Islam, karena pluralisme agama mengajarkan bahwa semua agama sama benarnya. Jika itu diyakini maka dapat mereduksi keimanan umat. Pluralisme agama menganalogikan agama seperti memakai baju, sehingga tergantung selera dan bisa berganti-ganti. Ajaran yang demikian jelas merusak dan mengarah pada pendangkalan dan relativisme agama. Kedua, pluralisme agama berimplikasi pada paham sinkretisme atau pencampuradukan agama. Hal tersebut tidak sejalan dengan pengertian pluralisme agama yang pernah dibahas dalam forum dialog antarumat beragama di Indonesia, yang digawangi oleh cendekiawan muslim A. Mukti Ali tahun pada tujuh puluhan, di mana disepakati pengertian adanya klaim kebenaran tiap agama, dan persetujuan dan perbedaan (agree in disagreement).

Ketiga, ajaran pluralisme telah banyak disosialisasikan secara aktif dan masif ke dalam lembaga-lembaga pendidikan, yang kemudian terpahami sebagaimana

68 lbid., 91-92.

69 Ibid., 93-95. pengertian para penganjurnya. Oleh sebab itulah MUI dalam Munas VII merasa perlu menyikapi usul dari masyarakat dan para ulama agar menetapkan fatwa terkait masalah pluralisme agama, untuk menghindarkan umat Islam Indonesia dari paham pluralisme agama. ${ }^{70}$ Keempat, diktum fatwa tentang pluralisme agama terbagi dalam dua bagian yang tidak terpisahkan, yaitu ketentuan umum dan ketentuan hukum. Dalam ketetapan hukum merujuk pada pengertian pluralisme yang telah ditulis dalam ketentuan umum. Pengertian pluralisme agama dalam ketentuan umum tersebut bersifat empiris, yang berarti bertitik tolak dari pengertian yang terpahami di masyarakat luas, sehingga bukan pengertian yang tanpa dasar dan mengada-ada, tetapi merespons dari yang selama ini telah disosialisasikan secara luas oleh penganjur pluralisme agama di masyarakat. ${ }^{71}$

Kelima, dalam fatwa MUI telah ditegaskan perbedaan pluralisme agama dan pluralitas agama yang berarti kemajemukan atau keragaman agama di suau wilayah. Indonesia sebagai suatu masayarakat dengan banyak agama adalah kenyataan yang tidak dapat disangkal, sehingga semua pihak termasuk umat Islam wajib menerima kenyataan tersebut sebagai keniscayaan dan menyikapinya dengan mengembangkan sikap menghargai, toleran, dan siap berdampingan dengan damai. Keenam, fatwa MUI terkait pengharaman pluralisme agama diorientasikan untuk membantah dan menangkal paham relativisme agama, yang menyatakan bahwa tidak ada kebenaran absolut dalam agama, semuanya bersifat relatif. Dalam fatwa tersebut justru

70 lbid., 93.

71 lbid., 94 
menggarisbawahi bahwa tiap agama dapat menyatakan klaim kebenarannya, tetapi harus berkomitmen untuk menghargai perbedaan, dan mewujudkan keharmonisan di masyarakat yang plural. ${ }^{72}$

\section{Kebenaran Fatwa MUI dan Keabsahan Makna Pluralisme Agama}

Sebagaimana dijelaskan MUI bahwa istilah pluralisme agama adalah istilah yang populer di masyarakat, namun tidak jarang pengertiannya dibelokkan dan disalahpahami. Sebagian ada yang memaknai pluralisme agama sama dengan pluralitas agama, ada juga yang memahami nya sebagai toleransi keberagamaan. Dari situlah MUI mendefiniskan pluralisme agama sebagai ajaran atau paham yang menyatakan bahwa semua agama sama, sehingga mengarah pada relativisme kebenaran agama. Menilik dari perkembangan konsep pluralisme maka definisi pluralisme MUI sejalan dengan yang dikemukakan oleh beberapa kalangan pluralisme seperti John Hick, W.C. Smith, dan lain-lain. Pluralisme yang mengarah pada pembentukan agama baru atau sinkretisme. Pluralisme yang didekati secara teologis filosofis.

Dalam penjelasan fatwa MUI tersebut, pemaknaan pluralisme berangkat dari apa yang dipahami oleh masyarakat umum. Dalam arti pemaknaan tersebut tidak dilakukan secara sepihak oleh MUI, tetapi dengan menjaring pengertian-pengertian yang dipahami oleh masyarakat muslim. MUI dalam pemaknaannya terhadap pluralisme tidak berangkat dari ruang kosong, tetapi memiliki basis empiris, serta melibatkan pula kalangan akademisi. Pengertian atau tipologi lain pluralisme memang masih sebatas dalam ranah akademik, sehingga wajar jika masyarakat muslim umumnya tidak memahami. Sementara jika pemaknaan pluralisme yang demikian (secara teologis) dibiarkan berkembang di masyarakat, tentu sangat membahayakan. Dari situlah MUI mengeluarkan fatwa pengharaman pluralisme karena bermakna sebagai paham relativisme keagamaan.

Tentu saja pemaknaan pluralisme yang demikian oleh MUI mendapatkan pertentangan dan menjadi kontroversi di kalangan akademisi, khususnya yang pro pluralisme. Mereka menilai fatwa tersebut berpotensi memicu konflik. Pertentangan tersebut karena terdapat perbedaan perspektif dalam memahami pluralisme. Sebagian akademisi mendekati secara sosiologis, pluralisme agama yaitu sebagai suatu sikap keterbukaan dan secara aktif menerima realitas perbedaan agama. Alihalih menganjurkan pluralisme agama yang pengertiannya bisa merancukan, maka MUI memilih dan mengakui pluralitas agama. Pluralitas agama berarti keragaman atau kemajemukan agama sebagai hukum sejarah (sunatullah) yang tidak mungkin terelakkan. Pluralitas agama adalah fakta Indonesia, yang harus disikapi secara toleran dan mengembangkan hidup berdampingan dengan damai. Pluralisme agama bukanlah arti lain dari Bhineka Tunggal lka yang menjadi semboyan bangsa Indonesia. Pengertian pluralisme yang berkembang di masyarakat justru mengarahkan seseorang untuk mempercayai relativisme kebenaran

72 Ibid., 95. 
karena semua agama sama dan sama-sama benar. Sedangkan sikap terhadap pluralitas agama menurut Islam adalah dengan mengakui dan menghormatinya tanpa bermaksud meyakini kebenaran masingmasing agama, karena agama yang benar adalah Islam. Sikap tersebut tertuang dalam prinsip "bagimu agamamu dan bagiku agamaku (lakum dinukum waliyadin)." Oleh sebab itu istilah pluralisme agama yang digunakan untuk alasan toleransi dan kerukunan hidup antarumat beragama layak ditolak oleh MUI. Sebab konsep pluralisme yang lahir di negara Barat, kemudian dikembangkan dan disebarluaskan kelompok-kelompok pro pluralisme maupun berpaham liberalisme memiliki arah pengertian yang cenderung berpotensi dipahami mencampuradukkan agama.

Anis Malik Thoha berpendapat bahwa istilah pluralisme agama dimengerti dan dirancang dalam frame logical positvisme, serta mendukung sekularisme dan liberalisme. Positivisme Barat diketahui mengesampingkan masalah-masalah metafisik dan teologis, karena kebenarannya tidak bisa diukur secara faktual dan empiristik. Agama sekadar dianggap respons manusia atau yang lazim disebut religious experience dengan menafikan mentahmentah keberadaan agama yang datangnya dari Tuhan. ${ }^{73}$ Sehingga term pluralisme agama adalah term yang baku dan bersifat teknis (a technical term). Untuk menjelaskan definisinya tidak cukup sekadar merujuk kamus bahasa, karena berdasarkan arti dalam kamus, pluralisme yang berarti menghargai dan menghormati perbedaan,

\footnotetext{
73 Thoha, Trend Pluralisme Agama, 125.

${ }^{74}$ Anis Malik Thoha. "Doktrin Pluralisme Agama; Telaah Konsep dan Implikasinya bagi Agama-Agama,"
}

serta keunikan semua agama, nyatanya pengertian tersebut berbeda secara diametral dengan pengertiannya secara teknis. $^{74}$

Lebih lanjut menurut Anis Malik Thoha, pengertian pluralisme agama yang tepat perlu dipahami dalam arti sosiologis bukan teologis, yaitu suatu keadaan hidup bersama atau koeksistensi antaragama yang berbedabeda dalam satu wilayah masyarakat dengan tetap mempertahankan ciri-ciri dan identitas khusus sebagai pokok ajaran tiap agama. ${ }^{75}$ Namun pengertian yang demikian tidak cukup populer di masyarakat, sebab para penganjur pluralisme agama sendiri tidak membatasi pengertian pluralisme agama sebatas secara sosiologis semata. Oleh sebab itulah menurut kesimpulan Ainul Yaqin bahwa pengertian pluralisme agama yang didefinisikan oleh MUI tidak salah. Pengertian tersebut tidaklah mengada-ada, bahkan pengertian yang telah disusun MUI juga mencakup dan sesuai dengan pengertian dari yang dikembangkan para penganjur pluralisme agama. ${ }^{76}$

Pemaknaan pluralisme agama tidak bisa disejajarkan dengan makna toleransi. Kedua konsep tersebut berangkat dari realitas yang berbeda. Dalam pluralisme agama tidak sekadar ada pengakuan eksistensi namun juga keabsahan agama lain. John Hick menyebutnya valid and authentic. Sedangkan toleransi sebatas mengakui eksistensi agama lain sebagai fenomena keragaman tanpa mereduksi kebenaran agama masing-masing. Toleransi tidak mengharuskan pengakuan validitas dan

Dialogia: Jurnal Studi Islam dan Sosial, vol. 9, no.1 (2011): 3.

${ }^{75}$ Anis Malik Thoha, Trend Pluralisme Agama, 14.

${ }^{76}$ Yaqin, Menolak Liberalisme Islam, 61. 
otentisitas agama lain secara akidah. Eksistensi semua agama diakui dan diterima tanpa adanya paksaan. Namun diyakini tidak semua agama benar. Di Islam diajarkan bahwa di luar golongan Islam adalah termasuk golongan yang merugi di akhirat kelak. Sehingga keberadaan agama lain diakui, tetapi kebenarannya ditolak. Mengakui pluralitas tetapi tidak mengakui pluralisme agama.

Makna pluralisme agama juga tidak bisa disamakan dengan kerukunan antarumat beragama. Penyamaan tersebut dikhawatirkan berakibat pada kekeliruan yang kemudian bisa menimbulkan konflik dan disharmoni di masyarakat. Hal tersebut seperti mengulang kasus fatwa kehadiran orang Islam dalam perayaan Natal umat Kristiani. Fatwa tersebut dikeluarkan tanggal 7 Maret 1982 guna menyikapi maraknya undangan-undangan perayaan Natal yang dihadiri oleh orang-orang Islam. Dalam fatwa tersebut dinyatakan bahwa haram hukumnya bagi orang Islam untuk turut hadir dan terlibat dalam upacara perayaan Natal. Hal tersebut karena ada yang menyamakan antara perayaan Natal dengan peringatan Maulid Nabi Muhammad yang dipandang tidak bersifat ibadah. Namun terdapat pula kasus penyelenggaraan perayaan Natal secara formal di lembaga pendidikan maupun instansi pekerjaan. ${ }^{77}$

Dalam konteks kerukunan beragama yang berharap mengarahkan umat Islam dalam kekristenan, maka ulama justru menganggapnya sebagai ancaman langsung kristenisasi. Mereka memandang bahwa bagi umat Kristen, perayaan Natal merupakan rangkaian ibadah yang apabila diikuti dapat mengganggu akidah umat Islam yang hadir dalam perayaan tersebut. Oleh sebab itu pelaksanaan kerukunan antarumat beragama dan perbaikan toleransi tidak bisa dilaksanakan dalam ranah akidah dan ibadah, tetapi dalam aktivitas-aktivitas sosial, kebangsaan, dan kerja sama dalam persoalan kehidupan dunia lainnya.

Pemaknaan pluralisme agama yang didefinisikan cenderung menggiring pada ajaran relativisme dan sinkretisme tersebut sangat beralasan. Yang apabila dibiarkan membawa efek pada pendangkalan akidah. Pengakuan terhadap kesamaan atau kebenaran semua agama, terlebih dengan analogi mengenakan baju yang bisa berganti-ganti, dapat berimplikasi bahwa setiap individu tidak perlu mengikuti agama tertentu, dia boleh berpindah-pindah atau berganti-ganti selayaknya ganti baju. Implikasi lebih jauh adalah individu akan memandang bahwa agama bisa tidak diperlukan atau hanya sekadar untuk memenuhi kebutuhan spiritualitas saja, yang itu nantinya bisa diganti dengan yang lainnya. Sehingga peran agama menjadi kecil dan dapat terhapus dalam kehidupan manusia. Oleh karenanya dapat dimengerti apabila MUI mengeluarkan fatwa untuk melarang paham pluralisme agama yang secara definisi bermakna teologis, dan dapat menggerus eksistensi iman umat Islam.

Ditinjau dari metodologi hukum, keberadaan Fatwa MUI Nomor 7 Tahun 2005 sebagaimana dijelaskan di atas, melandaskan pada metode mana yang paling kuat, atau unggul (bukan asal memilih). Menetapkan hukum dengan sesuatu yang tidak berdasar (unggul) sama

77 Mudzhar, Fatwa-Fatwa Majelis Ulama Indonesia, 117. 
seperti menetapkan hukum dengan dasar selain hukum Allah. Jadi kalau ada pendapat berbeda, dicari mana yang terunggul. ${ }^{78}$ Sebagaimana Keputusan ljtimak Ulama Komisi Fatwa Se-Indonesia Pertama Tahun 2003 tentang taswiyat al-manhaj (penyamaan pola pikir dalam masalahmasalah keagamaan) menyatakan bahwa perbedaan yang bisa diwajari dan ditoleransi adalah sifatnya dalam majal al-ikhtilaf (wilayah perbedaan) sehingga diupayakan mencari titik temu untuk keluar dari perbedaan (al-khuruj min al-khilaf). Sedangkan perbedaan di luar majal alikhtilaf tidak digolongkan sebagai perbedaan, melainkan merupakan penyimpangan atau penyelewengan ajaran Islam, seperti munculnya perbedaan terhadap masalah yang sudah jelas dan pasti ( $m a^{\prime}$ lum min al-din bi al-dlarurah), ${ }^{79}$ dalam hal akidah.

\section{Implikasi Fatwa Sebagai Landasan Dakwah Multikultural di Indonesia}

Sejak dahulu, wilayah Nusantara atau Indonesia dikenal memiliki keragaman budaya, etnis, suku, dan agama, sehingga corak multikultural bukanlah sesuatu yang baru. Keragaman keyakinan dan agama di Indonesia mendapatkan pengaruh dari banyak kebudayaan, seperti kebudayaan Hindu, Budha, Islam, dan Nasrani dari Eropa. Wilayah Nusantara yang terdiri atas kerajaan-kerajaan, mulai dari Sriwijaya, Majapahit, Samudra Pasai, Demak, Mataram, dan sebagainya. Sejak abad keenambelas dengan kedatangan para

\footnotetext{
78 Ibid.

79 Amin, Himpunan Fatwa Majelis Ulama Indonesia, 841.
}

bangsa asing dari Barat, yang dipelopori Portugis, Belanda, dan Inggris menjadikan wilayah Nusantara sebagai jajahannya sampai pada abad keduapuluh. Kesadaran kebangsaan kemudian tumbuh dan berkembang yang memuncak pada Kongres Pemuda Kedua dengan Sumpah Pemuda pada 28 Oktober 1928. Dari situ ada kebulatan tekad dan kesadaran bersama untuk mewujudkan persatuan sebagai jalan melawan penjajah. Kemudian, pada 17 Agustus 1945 wilayah bekas jajahan Belanda tersebut dapat merdeka dan lahir dengan nama Republik Indonesia. Para pendiri bangsa telah menyadari keragaman masyarakatnya dan bersepakat menjadikan Pancasila sebagai dasar negara, dengan semboyan "Bhineka Tunggal Ika" yang berarti berbeda-beda tetapi tetap satu jua. Filosofi dasar negara dan semboyan tersebut adalah wujud dari kesadaran kemajemukan jati diri bangsa Indonesia. ${ }^{80}$

Dakwah multikultural sebagai paradigma dakwah yang relatif baru dikembangkan relevan untuk konteks Indonesia yang multikultural. Namun dalam pelaksanaannya harus memperhatikan landasan terkait, salah satunya adalah fatwa MUI tentang pengharaman pluralisme agama. Hal tersebut penting, sebab konsep dakwah multikultural yang dikembangkan dari konsep multikulturalisme perlu menegaskan posisinya terkait hubungan atau perbedaannya dengan pluralisme. Sebagian kalangan ada yang mengganti istilah pluralisme dalam makna sosiologis dengan multikulturalisme, sebagaimana yang dilaksanakan oleh Forum Persaudaraan

80 Ahmad Syafii Maarif, Islam dalam Bingkai Keindonesiaan dan Kemanusiaan: Sebuah Refleksi Sejarah (Bandung: Mizan bekerjasama dengan Maarif Institute, 2009), 246 
Umat Beragama (FPUB) di Yogyakarta. ${ }^{81}$ Para aktivis dakwah Indonesia yang melaksanakan pendekatan multikultural perlu menjadikan fatwa MUI tentang pengharaman pluralisme sebagai landasan dakwahnya. Sebab MUI sebagai perwakilan kepemimpinan kolektif umat Islam Indonesia, telah memberikan responsnya terkait permasalahan keberadaan gagasan pluralisme yang bercorak relativisme dengan menetapkan fatwa haram terhadap pluralisme agama. Fatwa tersebut dapat menjadi asumsi dan rambu-rambu umum dalam pelaksanaan dakwah multikultural.

Untuk itu dengan keberadaan fatwa MUI sebagaimana di atas, berimplikasi terhadap beberapa aspek dalam pelaksanaan dakwah multikultural di Indonesia. Pertama, para aktivis dakwah multikultural harus menyadari bahwa paham pluralisme yang bercorak relativisme dan sinkretisme ada, disosialisasikan dan terus berkembang di masyarakat Indonesia, termasuk di kalangan umat Islam Indonesia.. Hal mana yang menjadi landasan bagi MUI dalam memaknai pluralisme itu sendiri. Kesadaran dan pemahaman ini penting, agar nantinya aktivitas dakwah multikultural tidak justru mengarah ke pluralisme, yang bisa berakibat menimbulkan polemik dan resistensi di masyarakat. Sehingga sejak awal bisa ditegaskan bahwa corak dakwah yang dikembangkan bukanlah berpaham pluralisme. Hal tersebut di antaranya dapat dilakukan dengan pengembangan materi dakwah yang menjelaskan tentang makna pluralitas dan nilai keharaman pluralisme teologis sebagaimana dijelaskan MUI, serta menjelaskan realitas pluralitas dan multikultural yang ada di Indonesia,

${ }^{81}$ Subkhan, Hiruk Pikuk Wacana Pluralisme di Yogya, 100. sehingga perlu mengembangkan sikap hidup bersama dengan damai dan toleransi aktif sebagai suatu wawasan kebangsaan. Melalui pengembangan materi dakwah antipluralisme dan promultikultural yang kontekstualnya berpijak pada kenyataan masyarakat Indonesia yang heterogen dan rasional, maka diharapkan terbentuk pemahaman yang tepat di masyarakat dan khususnya pelaku dakwah.

Mengikuti klasifikasi Bhiku Parekh tentang empat cakupan pembahasan multikultural, ${ }^{82}$ maka dakwah multikultural di Indonesia dapat dimasukkan sebagai kelompok counter of diversity, yaitu komunitas yang memberikan alternatif nilai di masyarakat terkait perkembangan wacana multikultural karena adanya pengaruh sebelumnya, seperti pemikiran pluralisme agama yang menyatakan semua agama sama.

Kedua, dalam fatwa MUI disebutkan menolak pluralisme dan menerima pluralitas. Hal tersebut sebenarnya sejalan dengan karakteristik dakwah multikultural yang menghargai perbedaan, dan membingkainya dalam konsep budaya toleransi dan harmoni sosial. Maka implikasinya adalah bahwa dalam pelaksanaan dakwah multikultural harus mengembangkan pendekatan yang bersifat dialogis dan tanpa pemaksaan. Hal tersebut berarti strategi dan komunikasi dakwah disusun dengan memperhatikan peta dimensi perbedaan budaya antara Dai dan mad'uw. Melalui analisis peta tersebut dapat dikembangkan strategi dan pola komunikasi dakwah yang ramah, di antaranya dengan memanfaatkan mediamedia kultural di masyarakat, seperti seni,

82 Bhiku Parekh, Rethinking Multiculturalism (London: Sage Publication, 2007), 176. 
dan sebagainya. Hal tersebut sejalan dengan berbagai pendekatan dakwah multikultural yang digagas Ismail dan Hotman, yang salah satunya menyebutkan menggunakan perangkat kultural dalam dakwah daripada yang bersifat harakah/gerakan. Contoh konkret sebuah pemahaman dan penghayatan dakwah multikultural adalah peristiwa Fath al-Makkah. Nabi tidak melakukan upaya balas dendam melainkan Beliau memberi kebebasan umat untuk mengikuti agamanya. Agama-agama lain diakui keberadaannya dengan interaksi sosial antarumat beragama yang toleran dan saling menghargai, sehingga menggambarkan moral keberagamaan yang dialogis dan terbuka. ${ }^{83}$

Ketiga, implikasi lebih lanjut terkait pengharaman pluralisme dan penerimaan pluralitas adalah terkait penyikapan terhadap perbedaan pemikiran dalam dakwah multikultural. Adanya perbedaan pemikiran dalam dakwah, perlu disikapi dengan dialog, keterbukaan, dengan orientasi pada pemecahan masalah. Apabila tidak didapatkan titik temu, maka tidak boleh ada pemaksaan atau intimidasi, melainkan penerimaan dan penghargaan terhadap perbedaan.

Dengan keberadaan fatwa MUI yang mengharamkan pluralisme agama maka secara prinsip lima pendekatan dakwah multicultural yang digagas oleh Ismail dan Hotman, masih relevan untuk dilaksanakan. Namun hal tersebut tetap perlu ditinjau dengan landasan hukum selainnya yang terkait. Sebagai catatan terkait arah dakwah yang mengusulkan bersifat lebih ke internal dengan berorientasi kualitas perlu ditinjau kembali kesesuaiannya dengan fikih dakwah, apakah ada pembatasan yang demikian dalam konteks tertentu. Walhasil sebagai sebuah gagasan dakwah, pendekatan multikultural perlu untuk terus mendapatkan penguatan melalui pengkajian akademik dan praktis.

\section{Kesimpulan}

Gagasan dakwah multikultural yang bersinggungan dengan konsep pluralisme perlu memperhatikan fatwa MUI tentang pluralisme agama sebagai salah satu landasan pelaksanaannya. Dari maraknya ajaran pluralisme agama yang terus dikumandangkan di masyarakat, dan dikhawatirkan akan mengakibatkan terjadinya pendangkalan akidah sebagai implikasi dari pemahaman menyamakan semua agama, yang juga menghilangkan identitas kebenaran Islam, maka MUI mengeluarkan fatwa Nomor 7 Tahun 2005 tentang keharaman pluralisme agama. Dengan mempertimbangkan ketentuan umum yang bersifat empiris, maka berdasarkan Al-Qur'an dan hadis yang dijadikan sumber hukum dan dalil dalam memutuskan hukum pluralisme agama, maka pluralisme agama dalam perspektif MUI adalah ajaran yang bertentangan dengan Islam sehingga bernilai haram. Makna pluralisme yang disampaikan oleh MUI dalam fatwa tersebut absah karena berasal dari pengertian asalnya dan berangkat dari pemahaman real di masyarakat. Meskipun menolak pluralisme agama, Majelis Ulama Indonesia menerima pluralitas sebagai kenyataan yang harus

${ }^{83}$ M. Amin Abdullah, Studi Agama Normativitas atau Historisitas? (Yogyakarta: Pustaka Pelajar, 2004), 74. 
disikapi dengan toleransi atau hidup berdampingan dengan umat beragama lain.

Implikasi keberadaaan fatwa MUI tentang pengharaman pluralisme bagi pelaksanaan dakwah multikultural di Indonesia, di antaranya menyangkut tiga hal, yaitu, pertama, perlunya kesadaran bagi aktivis dakwah multikultural terkait paham pluralisme melalui materi dakwah antipluralisme, sisi lain perlu mengembangkan materi dakwah yang bercorak promultikultural. Kedua, terkait metode dakwah bercorak kultural, yang disusun atas dasar analisis peta dimensi kultural Dai dan mad'uw. Ketiga, dalam menyikapi perbedaan adalah melalui dialog, keterbukaan, dengan orientasi pemecahan masalah.

Sebagai hasil rekomendasi dari studi ini adalah perlunya penguatan konsep dakwah multikultural dengan pengembangan studi yang bersifat akademik maupun praktik di lapangan. Hal tersebut menjadi tugas dan tantangan bagi akademisi dan praktisi dakwah di Indonesia. Mengingat Indonesia adalah negara multikultural, maka pendekatan dakwah multikultural perlu untuk terus dikembangkan.

\section{Bibliografi}

Abdalla, Ulil Abshar. "Pluralisme dan Pluralitas: Dua Sisi dari Koin Yang Sama." Islamlib. Mei 10, 2016. http://islamlib.com/gagasan/pluralisme/pluralisme-dan-pluralitas-dua-sisi-darikoin-yang-sama/.

Abdullah, M. Amin. Studi Agama: Normativitas atau Historisitas?. Yogyakarta: Pustaka Pelajar, 2004.

Al-Munawar, Said Agil Husin. Fikih Hubungan Antar Agama. Jakarta: Ciputat Press, 2003.

Amin, Ma'ruf. Himpunan Fatwa Majelis Ulama Indonesia Sejak 1975. Jakarta: Erlangga, 2011.

Arifin, Syamsul. Merambah Jalan Baru dalam Beragama: Rekonstruksi Kearifan Perenial Agama Dalam Masyarakat Madani dan Pluralitas Bangsa. Yogyakarta: Ittaqa Press, 2001.

Aziz, M. Ali. Ilmu Dakwah Edisi Revisi. Jakarta: Kencana Prenada Media Grup, 2016.

Badan Litbang Agama dan Diklat Keagamaan Departemen Agama Rl. Fatwa Majelis Ulama Indonesia (MUI) dalam Perspektif Hukum dan Perundang-undangan. Jakarta: Puslitbang Lektur dan Khazanah Keagamaan Badan Litbang dan Diklat Kemenrian Agama RI, 2012.

Basit, Abdul. Filsafat Dakwah. Jakarta: Rajagrafindo Persada, 2013.

Bisri, Achmad. “Islam Raḥmatan Li 'I-'Ālamīn sebagai Landasan Dakwah Multikultural: Perspektif Muhammad Fethullah Gülen.” Walisongo vol. 22, no. 02 (2014): 479-494. DOI: 10.21580/ws.22.2.290.

Departemen Agama R.I. Al-Qur'an dan Terjemahnya, Juz 1-30. Surabaya: Karya Agung, 2006.

Departemen Pendidikan dan Kebudayaan. Kamus Besar Bahasa Indonesia. Edisi II. Jakarta: Balai Pustaka, 1994.

"Dukung Pahlawan Nasional, MUI Jatim Tolak Gus Dur Bapak Pluralisme." nuonline. February 27, 2017. https://www.nu.or.id/post/read/21085/dukung-pahlawan-nasional-mui-jatimtolak-gus-dur-bapak-pluralisme.

Edwards, Paul. The Encyclopedia of Philosophy, Volume 5. New York: Mac Milan Publishing, 1967. 
Esack, Farid. Qur'an, Liberation and Pluralism: An Islamic Perspective of Interreligious Solidarity Against Oppression. England: Oneworld Publications, 1997.

Ghanoushi, Sheikh Rashid. "Pluralisme dan Monoteisme dalam Islam." Dalam Mansoor al-Jamri (ed.). Islamisme, Pluralisme dan Civil Society. Terj. Machnun Husein. Yogyakarta: Tiara Wacana, 2007.

Hick, John. "Religious Pluralism." Dalam Mircea Eliade (Ed.), et al. The Encyclopedia of Religion, New York: Simon \& Schuster Macmillan, 1995.

Hooker, M.B. Islam Mazhab Indonesia: Fatwa-fatwa dan Perubahan Sosial. Translated by Iding Rosyidin Hasan. Jakarta: Teraju, 2002.

Ismail, A. Ilyas dan Prio Hotman. Filsafat Dakwah: Rekayasa Membangun Agama dan Peradaban Islam. Jakarta: Kencana Prenada Media, 2011.

Kamus Besar Bahasa Indonesia, Offline Versi 1.1, 2010.

Kimlicka, Willy. Kewargaan Multikultural. Jakarta: LP3ES, 2003.

Kristianto, Aris. "Pluralisme Agama di Indonesia: Studi Tentang Tipologi Pluralisme Agama Nonindifferent Pada Keputusan Fatwa MUI Nomor 7 Tahun 2005." Disertasi, UIN Sunan Ampel Surabaya, 2018.

Maarif, Ahmad Syafii. Islam Dalam Bingkai Keindonesiaan dan Kemanusiaan: Sebuah Refleksi Sejarah. Bandung: Mizan dan Maarif Institute, 2009.

Misrawi, Zuhairi. "Rethinking Pluralisme Telaah Konsep dan Implementasi dalam kehidupan Sosioreligius di Indonesia." Dialogia Jurnal Studi Islam dan Sosial vol. 9, no. 1 (Juni 2011).

Mudzhar, Mohammad Atho. Fatwa-Fatwa Majelis Ulama Indonesia: Sebuah Studi tentang Pemikiran Hukum Islam di Indonesia, 1975-1988 (edisi dwibahasa). Jakarta: INIS, 1993.

Nafi'a, IIman. "Fatwa Pluralisme dan Pluralitas Agama MUI Dalam Perspektif Tokoh Islam Cirebon." Holistik vol. 14, no. 1 (2013): 125-150. DOI: 10.24235/holistik.v14i1.184.

Nawawi, "Dakwah dalam Masyarakat Multikultural." Komunika vol. 06, no.01 (Januari-Juni: 2012). DOI: 10.24090/komunika.v6i1.347.

Nawawi, Ismail. Metode Penelitian Kualitatif. Jakarta: Dwiputra Pustaka Jaya, 2012.

Parekh, Bhiku. Rethinking Multiculturalism. London: Sage Publication, 2007.

Permana, Andi. "Analisis Fatwa MUI Tentang Pluralisme, Liberalisme, dan Sekularisme Agama." Skripsi, UIN Syarif Hidayatullah Jakarta, 2017.

Qodir, Zuly. "Pemikiran Islam, Multikulturalisme dan Kewargaan." Dalam Wawan Gunawan Abd. Wahid, dkk, Fikih Kebinekaan: Pandangan Islam Indonesia Tentang Umat, Kewargaan, dan Kepemimpinan Non-Muslim. Bandung: Mizan, 2015.

Qarḍawi, Yusuf. Fiqh Prioritas. Mansyurat Kuliah Da'wah Islamiyah, 1990.

Rosidi, "Dakwah Multikultural di Indonesia:Studi Pemikiran dan Gerakan Dakwah Abdurrahman Wahid." Analisis vol. 13, no. 2 (2013): 481-500. DOI: 10.24042/ajsk.v13i2.708.

Setiadi, Elly M. dan Usman Kolip. Pengantar Sosiologi, Pemahaman Fakta dan Gejala Permasalahan Sosial: Teori, Aplikasi, dan Pemecahannya. Jakarta: Kencana Prenada Media, 2011.

Su'aidi, Agus Ahmad. "Mengukur Kuasa Fikih dan Teologi Atas Pemikiran: Studi Kasus Fatwa Pengharaman Liberalisme, Sekularisme, dan Pluralisme," ljtihad: Jurnal Wacana Hukum Islam dan Kemanusiaan vol. 10, no. 1 (2010): 17-33. DOI: 10.18326/ijtihad.v10i1.17-33. 
Subkhan, Imam. Hiruk Pikuk Wacana Pluralisme di Yogya: City of Tolerance. Yogyakarta: Impulse (Institut for Multiculturalism and Pluralism Studies) dan Kanisius, 2007.

Thoha, Anis Malik. Trend Pluralisme Agama: Tinjauan Kritis. Jakarta: Perspektif, 2006. . "Doktrin Pluralisme Agama: Telaah Konsep dan Implikasinya bagi AgamaAgama." Dialogia: Jurnal Studi Islam dan Sosial vol. 9, no.1 (2011): 1-14. http://irep.iium.edu.my/23866/1/Doktrin Pluralisme Agama.pdf.

Waskito, Abu Muhammad. Cukup 1 Gus Dur Saja!: Sebuah Monumen Kontroversi, Kebodohan Sistemik dan Kerancuan Berfikir Bangsa. Jakarta: Pustaka Al-Kautsar, 2010.

Yasin, Taslim H.M. "Pluraslime Agama Sebuah Keniscayaan." Substantia: Jurnal IImu-Ilmu Ushuluddin vol. 15, no. 1 (2013):134-144. DOI: 10.22373/substantia.v15i1.4890.

Yaqin, Ainul. Menolak Liberalisme Islam: Catatan Atas Berbagai Wacana dan Isu Kontemporer. Surabaya: Majelis Ulama Indonesia Provinsi Jawa Timur, 2012.

Yunus, Mochammad. "MUI Jatim Tolak Gelar Bapak Pluralisme" Asshomadiyahcenter. April 19, 2014. http://asshomadiyahcenter.blogspot.com/2011/10/mui-jatim-tolak-gelar-bapakpluralisme.html. 
Aris Kristianto

Dedy Pradesa 